\title{
Congo Basin peatlands: threats and conservation priorities
}

\author{
Greta C. Dargie $^{1,2,3}$ • Ian T. Lawson ${ }^{3} \cdot$ Tim J. Rayden ${ }^{4}$ • \\ Lera Miles $^{5} \cdot$ Edward T. A. Mitchard $^{6} \cdot$ Susan E. Page $^{7}$ • \\ Yannick E. Bocko ${ }^{8}$ - Suspense A. Ifo ${ }^{9}$ - Simon L. Lewis ${ }^{1,2}$
}

Received: 11 August 2017 / Accepted: 3 December 2017 / Published online: 16 January 2018

(C) The Author(s) 2018. This article is an open access publication

\begin{abstract}
The recent publication of the first spatially explicit map of peatlands in the Cuvette Centrale, central Congo Basin, reveals it to be the most extensive tropical peatland complex, at ca. $145,500 \mathrm{~km}^{2}$. With an estimated $30.6 \mathrm{Pg}$ of carbon stored in these peatlands, there are now questions about whether these carbon stocks are under threat and, if so, what can be done to protect them. Here, we analyse the potential threats to Congo Basin peat carbon stocks and identify knowledge gaps in relation to these threats, and to how the peatland systems might respond. Climate change emerges as a particularly pressing concern, given its potential to destabilise carbon stocks across the whole area. Socio-economic developments are increasing across central Africa and, whilst much of the peatland area is protected on paper by some form of conservation designation, the potential exists for hydrocarbon exploration, logging, plantations and other forms of disturbance to significantly damage the peatland ecosystems. The low level of human intervention at present suggests that the opportunity still exists to protect the peatlands in a largely intact state, possibly drawing on climate change mitigation
\end{abstract}

Greta C. Dargie

greta.dargie@btinternet.com

1 School of Geography, University of Leeds, Leeds LS2 9JT, UK

2 Department of Geography, University College, London WC1E 6BT, UK

3 Present address: Department of Geography and Sustainable Development, University of St Andrews, St Andrews KY16 9AL, UK

4 Wildlife Conservation Society, 2300 Southern Boulevard, Bronx, NY 10460, USA

5 UN Environment World Conservation Monitoring Centre, 219 Huntingdon Road, Cambridge CB3 ODL, UK

6 School of GeoSciences, University of Edinburgh, Edinburgh EH9 3FF, UK

7 School of Geography, Geology and Environment, University of Leicester, Leicester LE1 7RH, UK

8 Faculté des Sciences et Techniques, Université Marien Ngouabi, Brazzaville, Republic of the Congo

9 Ecole Normale Supérieure, Université Marien Ngouabi, Brazzaville, Republic of the Congo 
funding, which can be used not only to protect the peat carbon pool but also to improve the livelihoods of people living in and around these peatlands.

Keywords Congo $\cdot$ Carbon $\cdot$ Conservation $\cdot$ Peat $\cdot$ Threats

\section{Introduction}

The Cuvette Centrale, in the central Congo Basin, is the second-largest wetland in the tropical latitudes. Recent research suggests that many of the swamp forests that occupy the basin are underlain by peat spanning an estimated $145,500 \mathrm{~km}^{2}$, that store ca. 30.6 petagrams $(\mathrm{Pg} ; 1 \times$ $10^{15} \mathrm{~g}$ ) of carbon (Dargie et al. 2017). This makes the Cuvette Centrale-spanning both the Republic of Congo (ROC) and Democratic Republic of Congo (DRC) - the single largest peatland complex known in the tropics (Dargie et al. 2017), with a belowground carbon stock equivalent to that of the aboveground tropical forest carbon stocks for the entire Congo Basin (Saatchi et al. 2011; Verhegghen et al. 2012). The discovery of so much peat in the Congo Basin has forced a re-evaluation of the role of Congolese swamps in the global carbon cycle. We need to know whether the peatland carbon stocks are stable, or whether they are at risk from perturbations by people and/or climate change; and we need to know what actions could be taken to minimise any threats.

Recently, Roucoux et al. (2017) reviewed the potential threats to intact tropical peatlands and their conservation opportunities, with a particular focus on the peatlands of the PastazaMarañón Foreland Basin in Peru. In this paper, we build on their work by analysing the potential threats to the stability of carbon storage in the Congo Basin peatlands, and to the integrity of these ecosystems more generally. We then consider the forms of protection currently in place and the ways in which these may be extended. Finally, we identify priorities for future research aimed at informing conservation, management and development in the region.

\section{Study area}

Recent scientific research in the Cuvette Centrale by Dargie et al. (2017) has focused on providing a first estimate of carbon storage and the distribution of peat. Peat and the overlying vegetation was sampled along $57.5 \mathrm{~km}$ of transects, distributed across a wide area of the basin west of the Ubangui river in the ROC. Some 211 measurements of peat thickness, and samples of carbon density from 44 cores, together with data on vegetation composition and structure, were used to model the distribution of vegetation and peat carbon storage across the whole of the Cuvette Centrale. Relatively few ground reference points were available from the DRC, or the southern part of the basin within the ROC, which contributes to considerable uncertainty in the estimated carbon stock; 95\% confidence intervals for the peat carbon stock estimate range from 6.3 to $46.8 \mathrm{Pg}$, largely owing to highly variable peat depth. Basal radiocarbon dates indicate that peat began to accumulate during a period of increasing climatic wetness in the early Holocene (the African Humid Period; Shanahan et al. 2015), beginning approximately 10,600 calendar years before present (BP, present defined as 1950; Dargie et al. 2017). Hydrological and geochemical data indicate that at present, rainfall makes a substantial direct contribution to the water 
balance of the sites that have been studied; flooding by rivers appears to be of secondary importance (Dargie et al. 2017). Despite these advances in our knowledge of present-day carbon storage, there are still large gaps in our understanding of these ecosystems, including their topography and hydrology, past and present carbon storage dynamics and the past and present ecology of the hardwood and palm swamps associated with peat (Fig. 1).

Previous scientific research on the region has focused primarily on large mammals (Fay and Agnagna 1991; Inogwabini et al. 2012). The Cuvette Centrale has long been famous for its megafauna populations. Substantial numbers of lowland gorilla (Gorilla gorilla gorilla), forest elephant (Loxodonta cyclotis), chimpanzee (Pan troglodytes) and bonobo (Pan paniscus) find refuge in the swamp forests (Fay and Agnagna 1991; Rainey et al. 2010; Inogwabini et al. 2012) along with smaller vertebrates including various monkeys and dwarf crocodile (Osteolaemus tetraspis; Riley and Huchzermeyer 1999). A full species inventory of flora and fauna remains to be completed; there is very little information on, for example, plants, fish and invertebrates.
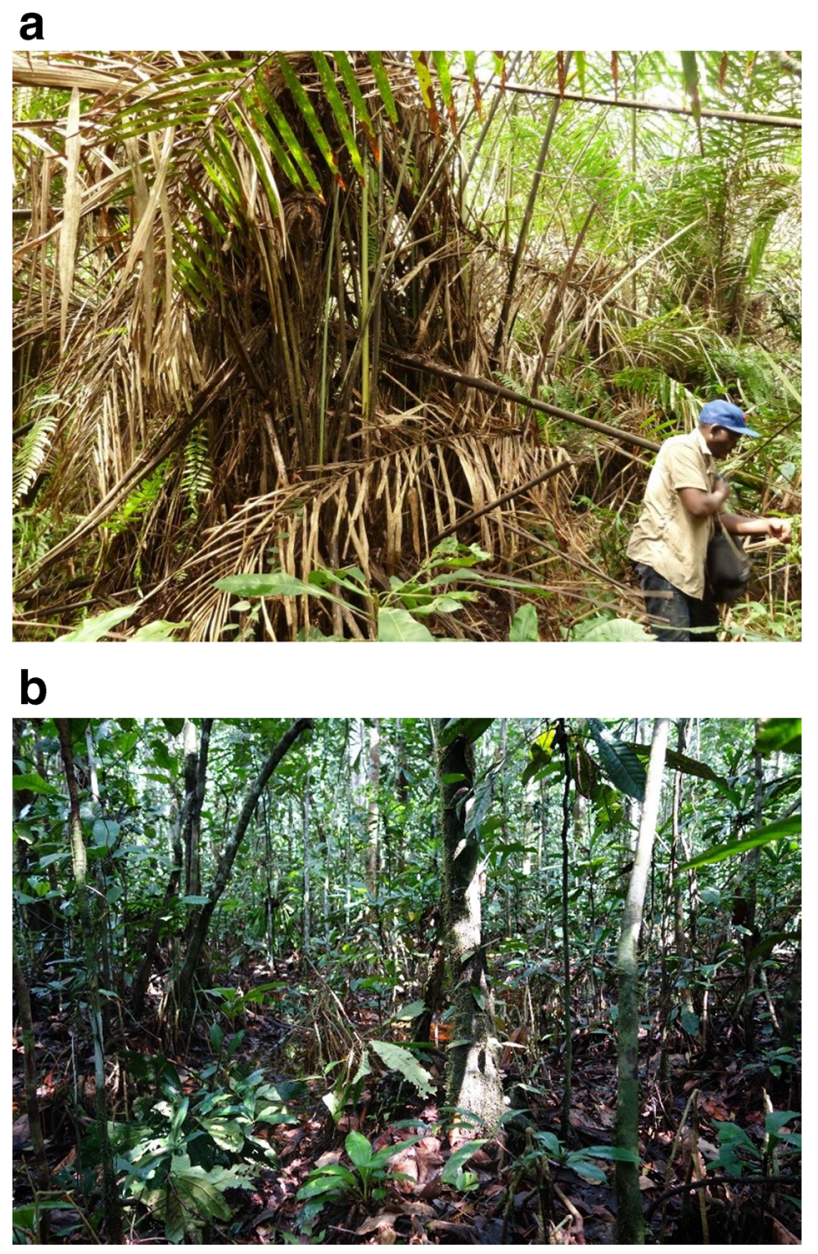

Fig. 1 Overlying vegetation of the Cuvette Centrale peatlands. a Palm-dominated swamp (credit I.T. Lawson) and $\mathbf{b}$ hardwood swamp (credit S.L. Lewis) overlying peat in the Likouala Department, Republic of Congo 
There have also been a number of studies of river water chemistry (Laraque et al. 2001, 2009), the geological origins of the basin (Daly et al. 1992; Crosby et al. 2010; Kadima et al. 2011; Buiter et al. 2012), remote-sensing-based studies of hydrology and vegetation distribution (Mayaux et al. 2004; Vancutsem et al. 2009; Bwangoy et al. 2010; Jung et al. 2010; Betbeder et al. 2014; Lee et al. 2015), and the contested origins of Lac Télé (Master 2010). None of these studies have taken account of the status of the Cuvette Centrale as a major peatland complex, but many of them are, with hindsight, relevant to understanding the system as a whole.

Although it is considered by many outsiders as a wilderness, people reside throughout the Cuvette Centrale, in both the ROC and DRC, mainly in villages or small towns along the river or road transport networks. People of Bantu origin make up the largest ethnic group in the region and often lead a subsistence livelihood focused on fishing and small-scale farming of crops such as manioc (Manihot esculenta) and banana (Musa spp.), and limited numbers of livestock including goats and chickens. Bantu populations likely arrived in the region within the last 2000 years (Brncic et al. 2007), whereas autochthonous (i.e. indigenous) huntergatherer groups have been present for much longer (possibly since as far back as 40,000 years BP; Oslisly et al. 2006). Whilst some autochthonous communities still lead a fully nomadic lifestyle, colonial and post-colonial governmental resettlement policies, exclusion from customary access to forest resources and economic attractions have seen an increase in the number of communities either pressurised into or voluntarily choosing a semi-nomadic or sedentary lifestyle (Lewis 2002; Riddell 2013). Across the Cuvette Centrale, people rely in part on peat forest resources for their livelihoods. This is particularly true for the autochthonous communities, and as a result, the impacts of industry (such as forest degradation) or conservation (forest access restrictions) activities in the region are often felt more keenly by these communities (Lewis 2002; Riddell 2013). At the same time, the social marginalisation of autochthonous communities means they are often neither meaningfully involved in consultation processes nor able to benefit economically from the arrival of these activities (Lewis 2002; Riddell 2013).

\section{Threats}

\subsection{Climate change}

The future impact of anthropogenic greenhouse gas emissions on the regional climate of the Congo Basin is clear for temperature; the region will warm, with the magnitude dependent on the level of greenhouse gas emissions. Under the Representative Concentration Pathway (RCP) 2.6, mean annual temperature is predicted to increase by ca. $0.5{ }^{\circ} \mathrm{C}$ from the end of the twentieth century to the the end of the twenty-first century and by ca. $4.3{ }^{\circ} \mathrm{C}$ under RCP8.5 (Niang et al. 2014). However, modelled projections show no clear consensus for changes in regional precipitation. Some models point towards a decrease in precipitation levels across the basin towards the end of the twenty-first century (James et al. 2013; Fotso-Nguemo et al. 2016), whilst others suggest there will be little or no change in overall precipitation or even a slight increase (Haensler et al. 2013; Laprise et al. 2013). Even where there is no change in overall precipitation levels, some models show changes in the characteristics of the rainfall regime, for example an increase in rainfall intensity and frequency of dry periods (Haensler et al. 2013). 
The lack of certainty on the future of the Congo Basin climate is the result of a number of factors. Firstly, there is a lack of observational data from the region (Giles 2005), which would allow model performance to be assessed by their ability to recreate present-day climates. Secondly, the spatial resolution of the models differ, with lower resolution models less able to represent the complexities of the climate system within the basin (Haensler et al. 2013; Laprise et al. 2013). Finally, differences in the structure of the models, such as how different processes are represented, will contribute to the divergence in climate projections (Barnston et al. 2012).

The Congo Basin peatlands appear to depend largely on rainfall to maintain a positive water balance (Dargie et al. 2017). The bimodal climate of the Congo Basin, with two wet seasons per year (March to May, September to November; Samba et al. 2008), means that the peatlands do not experience prolonged dry periods. However, the annual rainfall level across the Cuvette Centrale is relatively low for a tropical peatland system (ca. $1700 \mathrm{~mm}_{\text {year }}^{-1}$ (Samba et al. 2008); cf. Pastaza-Marañón, Peru, ca. 3000 mm year $^{-1}$ (Marengo 1998); Central Kalimanatan, Indonesia, ca. $2900 \mathrm{~mm}_{\text {year }}^{-1}$ (Susilo et al. 2013)). Therefore, a reduction in overall rainfall, a change in the temporal distribution of rainfall and higher evaporation under higher temperatures in the Congo Basin could all have a negative impact on the peatland carbon stocks. Drier conditions or an increase in the frequency of intense dry periods could lead to an increase in decomposition rates and a loss of carbon from the peatland system.

Whilst peat initiation appears to have been synchronous with, and therefore likely driven by, an increase in regional precipitation at the start of the Holocene, it is unclear how peat accumulation in the Cuvette Centrale has responded to subsequent climatic changes. Downcore radiocarbon dates from just one site (with three cores) show a period of low or negative peat accumulation (Dargie et al. 2017), the timing of which is not well constrained from the radiocarbon dates, but which appears to occur during the mid-Holocene. Peat accumulated more quickly during the past $\sim 2000$ years. This mid-Holocene slowdown or cessation of peat and carbon accumulation appears to coincide with the termination of the African Humid Period across the Cuvette Centrale region around 3000 years BP (Shanahan et al. 2015). Higher resolution radiocarbon dating of cores from several sites, accompanied by palaeoecological work, would help to build a clearer picture of how these peatlands have responded in the past to changes in regional precipitation and therefore give an indication of how they might respond in the future.

\subsection{Forestry and agriculture}

The conversion of peatlands to agricultural land often involves the lowering of the peatland water table by digging drainage canals. The more oxygenated conditions in the surface peat allow rapid decomposition of the organic matter (Hooijer et al. 2010). Even when there is no active drainage, the removal of trees from forested peatlands could lead to a reduction in organic matter inputs (Könönen et al. 2016) and the loss of canopy cover can expose the peat surface to higher temperatures, contributing towards drying (Jauhiainen et al. 2012) or can reduce evapotranspiration leading to an increase in waterlogging (Moore et al. 2013). Furthermore, drainage of the peatland increases the risk of subsidence (sometimes eventually flooding the land again) and fire occurrence (Page et al. 2002; Jauhiainen et al. 2012). As peatlands are often nutrient poor, acidic environments, conversion to agricultural land often requires the application of fertilisers, which can also enhance decomposition (Takakai et al. 2006).

Across the Cuvette Centrale, both in the ROC and DRC, present-day forestry and agricultural activities, whether small scale or industrial, appear to be largely confined to terra firme forest (Fig. 2a and personal observations). A large proportion of the residents of the Cuvette 

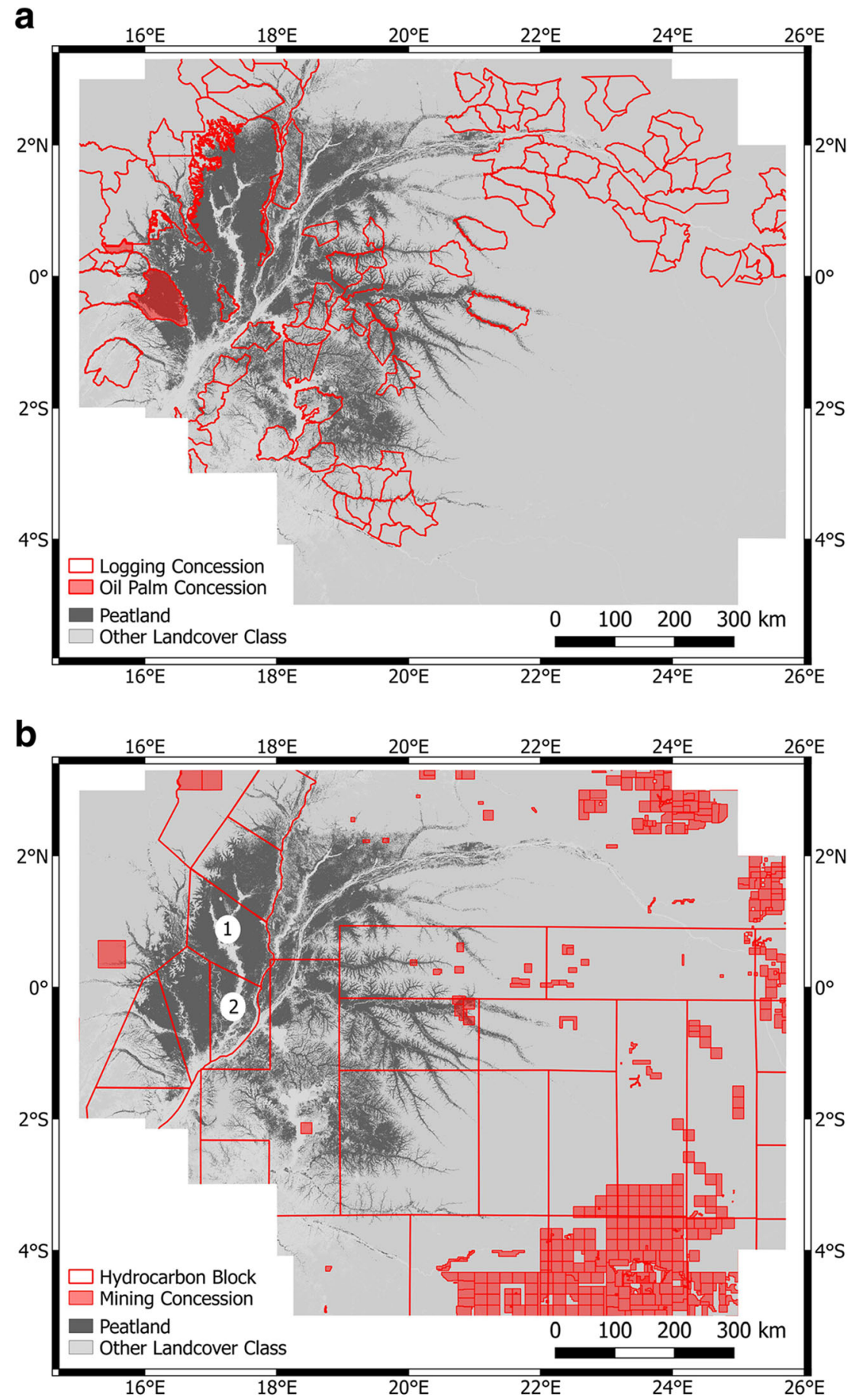
Centrale practice subsistence agriculture. Plots tend to be relatively small and located close to the villages or within the strips of terra firme forest. Local activity within the peatlands is limited to hunting and harvesting of forest products such as palm fronds for roof construction. From personal observations, the current impact of local residents on the peatland ecosystems is likely to be minor and relatively sustainable in its current form.

Approximately $29,000 \mathrm{~km}^{2}$ of mapped forested peatland are officially under a logging concession. However, commercial logging operations across the Cuvette Centrale appear not yet to have commenced in the peatland forests (Hansen et al. 2013). This is in part because there has been a moratorium on logging in the DRC since 2002, and in part because logging operations target terra firme forest in preference to swampy areas. A lifting of the moratorium to allow the expansion of large-scale selective logging in the DRC is under serious consideration, motivated by the desire to improve socio-economic development in the region and curb illegal, unregulated deforestation (Ministry of Climate and Environment, Kingdom of Norway 2017). However, any expansion of logging activity runs the risk that the peatlands will be affected, either directly by timber extraction or indirectly by infrastructure expansion, particularly changing drainage patterns following road construction (see section 3.4 below), unless operations are closely monitored and regulations enforced. These is also evidence from Africa that when governance is weak, frontier logging is the first step in waves of forest degradation ending in forest clearance (Ahrends et al. 2010).

At least one concession agreement has already been approved for oil palm plantations and other operations in the ROC part of the region, covering some $4700 \mathrm{~km}^{2}$ in total, of which ca. $4200 \mathrm{~km}^{2}$ is mapped as forested peatland (Fig. 2a; The Rainforest Foundation UK 2013). In South East Asia, oil palm plantations have been one of the main drivers of peatland degradation (along with Indonesia's unsuccessful 'Mega Rice Project' of the 1990s; Rieley 2001). Of the $4.3 \mathrm{M}$ ha of peatland in Peninsular Malaysia, Sumatra and Borneo that has now been converted to plantations, $73 \%$ is occupied by oil palm plantations (Miettinen et al. 2016). At present, Malaysia and Indonesia produce $85 \%$ of the world's palm oil (USDA Foreign Agricultural Service 2017), but with global demand set to increase and South East Asian productivity growth slowing (Wright and Rahmanulloh 2017), investment in oil palm in Africa is likely to increase in the coming years (Ordway et al. 2017), especially when the arrival of large oil palm companies in the Congo Basin is backed by international funds and government incentives, such as tax breaks (The Rainforest Foundation UK 2013).

\subsection{Mining and hydrocarbons}

The ROC is the fourth largest oil producer in sub-Saharan Africa (The Oil and Gas Year 2017a). Most of its hydrocarbon exploration and extraction activity is offshore, with extraction currently permitted in only one onshore hydrocarbon block, Kayo Sud, in the south of the country.

Fig. 2 Distribution of peatlands, concessions and protected areas within the Cuvette Centrale. Map of peatland distribution within the Cuvette Centrale (dark grey; Dargie et al. 2017), overlaid with the locations of a logging (red outline; Global Forest Watch 2017c, d) and oil palm (red fill; The Rainforest Foundation UK 2013) concessions, b hydrocarbon blocks (red outline; 1. Ngolo block; 2. Ngoki block; Ministère des Hydrocarbones Républic du Congo \& SNPC 2016; MapforEnvironment 2017a) and mining concessions (red fill; Global Forest Watch 2017a, b), c national protected areas (green fill; 1. Lac Télé Community Reserve; 2. Réserve NtokouPikounda; 3. Réserve Naturelle du Triangle de la Ngiri; 4. Réserve Tumba-Ledima; 5. Parc National de la Salonga; 6. Réserve Lomako Yokokala; MapforEnvironment 2017b; Protected Planet 2017) and d Ramsar sites (green fill; Protected Planet 2017; Ramsar 2017b) 

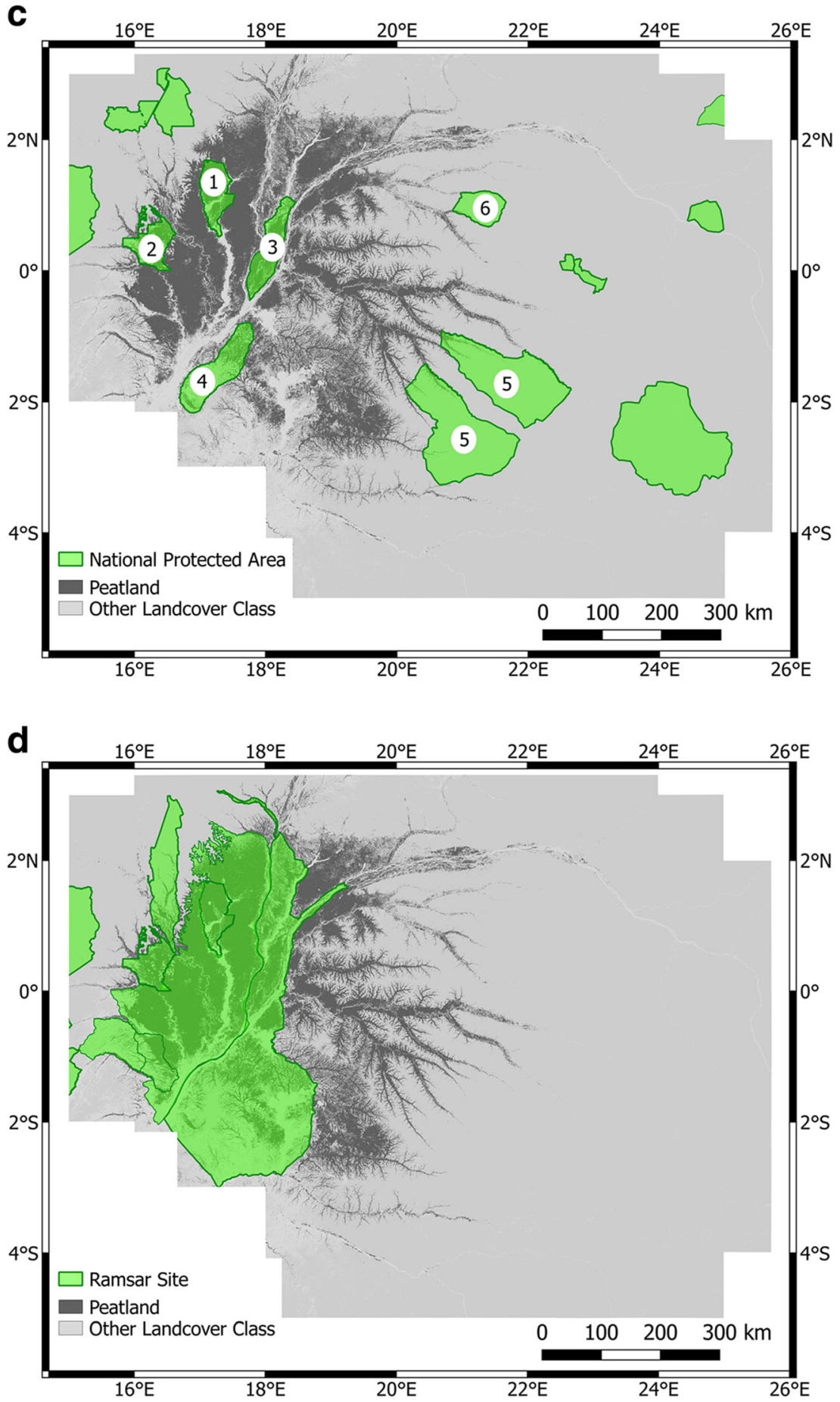

Fig. 2 (continued) 
Likewise, DRC hydrocarbon extraction is currently limited to offshore, with exploratory work now underway in eastern DRC (US Department of Commerce 2017). However, the ROC government appears open to developing onshore oil exploration in the Cuvette Centrale. In collaboration with international companies, exploration has been underway in the Ngolo and Ngoki blocks, both of which encompass large areas of peatland (Ministère des Hydrocarbones Républic du Congo \& SNPC 2016; Fig. 2b), since 2013 and 2016, respectively (The Oil and Gas Year 2017b). Whilst the remoteness of the region and the presence of wetlands are significant practical obstacles to oil extraction, the lack of geological survey data has until now been important in limiting investor interest in the Cuvette Centrale: only four wells, all within the DRC and all of them dry, have previously been drilled in the Cuvette Centrale (The Oil and Gas Year 2017b). The results of the hydrocarbon exploration in the Ngolo and Ngoki blocks will likely determine the level of investor interest in the future (The Oil and Gas Year 2017b).

Some of the major impacts of hydrocarbon exploration in other forested regions (such as Western Amazonia, also home to significant peatland ecosystems) have come from the construction of access roads (see 3.4 below) and pipelines (Roucoux et al. 2017). Deforestation is not only limited to the pathways of these roads and pipelines, but their construction opens up what was previously inaccessible forest to illegal logging and exposes faunal populations to increased hunting pressures (Finer et al. 2008). In addition to this are the risks of oil spills and wastewater damaging the peatland ecology, as observed in parts of Western Amazonia (Finer et al. 2008; Arellano et al. 2015).

Even excluding its oil reserves, the Congo Basin is one of the most mineral rich regions on the planet. The DRC is the world's largest producer of cobalt and is in the top ten producers of copper, diamonds, lithium, tantalum and tin (USGS 2016). Like oil exploration, mining activities bring the threat of deforestation and pollution from waste products. The launch of official mining activities is also often followed by unregulated artisanal mining, meaning that the area impacted is often greater than originally planned (Edwards et al. 2014). Across the DRC and ROC, there is some overlap between current mining concessions and modelled peatland (Global Forest Watch 2017a, b; Fig. 2b). However, this is limited to the margins of the peatland areas and the vast majority of mining concessions and known mineral deposits are in non-peatland areas (Edwards et al. 2014). Therefore, the current evidence suggests that whilst mining activities may have some impact on the Congo Basin peatlands, it is likely to be minimal.

\subsection{Transport infrastructure}

There are few roads within the Cuvette Centrale, with the rivers acting as the main transport network. This, together with the large distance from any international port and low population densities, is one of the reasons why the Congo Basin peatlands have so far been spared the fate of South East Asian peatlands. Recently, the ROC government invested 60 million Euros in a port upgrade for the capital city, Brazzaville (The Oil and Gas Year 2017b). One of the motivations for this investment is to improve access to the north of the country for hydrocarbon exploration.

Although limited in number, roads have already been constructed across some of the peatland areas of the Cuvette Centrale (e.g. between Epena and Impfondo, Likouala Department, ROC). No studies have yet considered the specific impacts of these roads on the peat properties, hydrology or vegetation, although personally observed swamp forest die back following road construction suggests that roads could be having a negative impact on the wetlands of the region. Roads can act as a barrier to ground water and channel flow, diverting 
or impeding water, leading to the desiccation of peat on the downside, increased flooding on the upside and/or erosion, which can cause changes in the vegetation community and carbon cycling in the peat (Patterson and Cooper 2007; Grootjans et al. 2010; Chimner et al. 2016). As for roads built for logging access or hydrocarbon infrastructure, these direct effects may be much less important than the indirect effects of facilitating access to previously remote regions; studies throughout the tropics have shown that road-building almost invariably leads to immigration and land-use conversion (Laurance et al. 2017).

\subsection{Hydroelectricity}

Since the 1950s, the DRC government has laid plans to construct a series of large hydroelectric dams on the Congo River, downstream of the capital Kinshasa, together known as the Grand Inga hydropower project. The Grand Inga scheme would have a final generation capacity of 40,000 MW, which would make it the largest hydroelectric scheme in the world (International Rivers 2017). In 2014, the World Bank agreed to invest US\$73.1 million in the initial stages of the project, but in 2016 this funding was halted 'following the government's decision to take the project in a different strategic direction to that agreed' (World Bank 2016). The DRC government is seeking alternative funding to continue the project (Fabricius 2016).

As our understanding of the link between peatland hydrology and the regional river system is at present very limited, the impact of such a project on the Congo Basin peatlands is unclear. Whilst it appears that river flooding is not the main source of water to the peatlands (Dargie et al. 2017), changes in regional hydrological gradients as a result of dam construction could impact on peatland hydrology, including even potentially reducing drainage from the peatlands, if the hydrological gradient between the peatlands and rivers is reduced. Whatever the effects, the construction of a large hydroelectric scheme without any environmental impact assessment of its potential effects on upstream ecosystems and their carbon stores (Fabricius 2016) is of concern.

Another development project which could have unintended consequences for the peatlands is an ambitious project to divert water from the right bank tributaries of the Congo River towards Lake Chad. The project, known as Transaqua, aims to replenish Lake Chad's diminishing water levels by constructing a canal which runs from the Kivu region of the DRC, through the Central African Republic (CAR), across the Congo-Chad Divide, eventually channelling the water into a Lake Chad tributary (Bonifica S.p.A 2017). It is also hoped that the project will generate energy through a series of hydroelectric dams along the route, as well as provide an irrigation source for the Sahel region and a new transport network to the Congo Basin (The Lake Chad Basin Commission 2016a). Although first proposed in the 1970s, the project is still at an early stage of development, with the most recent feasibility study agreed in December 2016 (The Lake Chad Basin Commission 2016a). However, this follows on from an earlier feasibility study which focused on the possibility of transferring water only from the Ubangui sub-basin, in CAR, and which concluded that the proposal was technically feasible and economically viable (The Lake Chad Basin Commission 2016b). If Transaqua goes ahead, it is estimated that between 50 and 100 billion cubic meters of water, equivalent to ca. 4 to $8 \%$ of the Congo River's annual discharge at its mouth, will be diverted away from the Cuvette Centrale (The Lake Chad Basin Commission 2016a; Bonifica S.p.A 2017). In terms of the threat to the peatlands, there is one notable difference between Grand Inga and Transaqua; the biggest advocates and beneficiaries of Transaqua, the member states of the Lake Chad Basin Commission (The Lake Chad Basin Commission 2016c), have little environmental, social 
or economic interest in ensuring the peatlands' conservation and would not have to deal with the consequences of perturbations to the peatlands. Whilst the DRC has control over whether Transaqua extends into its territory, it is possible that the DRC and ROC may ultimately have little say over Transaqua activities in the CAR. It is therefore important that those responsible for Transaqua are made fully aware of the value of the Cuvette Centrale peatlands and that the feasibility study and any subsequent detailed planning should evaluate the effects of Transaqua on the Cuvette Centrale peatlands, with the aim of mitigating its impacts through political or engineering solutions.

\subsection{Synergies of degradation}

Each of the potential threats to the Cuvette Centrale peatlands discussed above has been considered individually. However, the reality is that land-use changes occur in response to multiple complex and interacting environmental, economic and political factors, which can accelerate and/or exacerbate the negative impacts of any individual threat to the peatlands. A well-known example of this is the Indonesian government's failed Mega Rice Project, an initiative, begun in 1996, that aimed to convert a million hectares $\left(10,000 \mathrm{~km}^{2}\right)$ of Central Kalimantan's peatlands to rice cultivation (Rieley 2001). With Javanese rice paddies having been sold off for commercial and urban development projects, the Mega Rice Project was intended to increase Indonesia's food production and alleviate population pressures in Java, by bringing in Javan workers through a transmigration programme (Rieley 2001). With thousands of kilometres of drainage canals dug through the peatlands, lowering the water table and opening up the forest canopy, the drought during the 1997 El Niño event caused large fires to spread across the peatlands (Page et al. 2002). Covering more than $50 \%$ of the peatland area, these fires are estimated to have released between 0.12-0.15 Pg of carbon (Page et al. 2002). Although by 1999 , the project was abandoned by the government, peatland degradation continues in the region, as the drainage canals continue to dry the peatlands and the impoverished communities left behind continue forest conversion to agricultural land along these canals (Medrilzam et al. 2014). Annual fires continue (Langner and Siegert 2009) and are especially serious during El Niño events (most recently in 2015; Huijnen et al. 2016).

In the Cuvette Centrale, a hypothetical future situation with high commodity prices, improved road and river access to markets, higher temperatures and more frequent droughts, could replicate the conditions which led to the catastrophic peatlands fires seen in Indonesia. Given the historical difficulties of implementing strong environmental controls in remote areas of income-poor countries, whilst the Cuvette Centrale peatland areas may seem far from largescale degradation today, there is potential for the situation to change quickly.

\section{Prospects for conservation and research recommendations}

\subsection{Protected areas}

Some $16,600 \mathrm{~km}^{2}$ of the $145,500 \mathrm{~km}^{2}$ of peatlands, or $11 \%$, lies within official national protected area boundaries. In the ROC, the Lac Télé Community Reserve $\left(4600 \mathrm{~km}^{2}\right)$ and the Réserve Ntokou-Pikounda $\left(4400 \mathrm{~km}^{2}\right)$ cover 3500 and $3000 \mathrm{~km}^{2}$ of peatland, respectively (Fig. 2c). In the DRC, four reserves partially span peatland areas: the Réserve Naturelle du Triangle de la Ngiri $\left(5400 \mathrm{~km}^{2} ; 3900 \mathrm{~km}^{2}\right.$ peatland), the Réserve Tumba-Ledima $\left(7700 \mathrm{~km}^{2}\right.$; 
$2600 \mathrm{~km}^{2}$ peatland), the Parc National de la Salonga $\left(36,100 \mathrm{~km}^{2} ; 790 \mathrm{~km}^{2}\right.$ peatland) and the Réserve Lomako Yokokala $\left(3700 \mathrm{~km}^{2} ; 76 \mathrm{~km}^{2}\right.$ peatland).

In addition, very large areas of the peatlands, in both the ROC and DRC, are part of sites designated as Wetlands of International Importance (Ramsar sites) under the 1971 Ramsar Convention (Ramsar 2017a), which in some cases also overlap with the above-mentioned national protected areas (Fig. 2d). Indeed, both the ROC and DRC contain some of the largest Ramsar sites in the world (Ramsar 2017a). However, little has yet been done to translate their on-paper designation into actual rules of use on the ground. The Ramsar Convention requires Contracting Parties (i.e. nation states) to promote the wise use of wetlands, including in their land-use planning, and has a specific 2015 agreement on peatlands (Ramsar 2015), but wise use is a broad concept and the Convention does not require that a legally protected status should be given to a Ramsar site (Ramsar Convention Secretariat 2016). The expectation is that conservation plans are developed and implemented for the listed sites. But whilst the Ramsar Convention provides a framework to promote the protection of the Cuvette Centrale wetlands, without sufficient funds being invested in the management of these sites, it appears that active protection is still lacking.

A further concern is that the protected areas in the Cuvette Centrale have been established without the recognition that they include peatlands. This is important because peatlands function as hydrological landscape units; damage to one part of the peatland may have wide-reaching consequences, because of the hydrological connectedness of the system as a whole. Furthermore, Cuvette Centrale peatlands appear to cover unusually large areas. Individual peatlands, operating as a single hydrological unit, appear to occupy entire interfluvial basins, up to ca. $50 \mathrm{~km}$ across. Protected areas that only encompass parts of a peatland unit may therefore still be prone to degradation due to activities outside the protected area boundary, impacting on peatland carbon stocks and reducing the effectiveness of that protected area in achieving its biodiversity conservation goals. One option to manage the unit as a whole would be to extend the boundaries of existing protected areas to the hydrological boundaries of the peatlands that they encompass. It remains unclear to what extent the peat itself is critical to sustaining the biodiversity that is so valued. Some species - for example, dwarf crocodiles - do make use of the peat itself for nesting burrows (Riley and Huchzermeyer 1999), and the abundance of herbaceous vegetation in the swamp forests provides a valuable food resource for primate species (Fay et al. 1989; Hashimoto et al. 1998; Terada et al. 2015). More research is badly needed, but the presence of large carbon stores can only enhance the combined biodiversity and ecosystem service value of the peatlands.

\subsection{Climate funding}

The presence of so much carbon stored in peat in the Cuvette Centrale opens the possibility of attracting climate change mitigation funding to the region. The United Nations Framework Convention on Climate Change (UNFCCC) Reduced Emissions from Deforestation and Forest Degradation (REDD+) mechanism (UN-REDD Programme 2016) and related voluntary carbon offsetting schemes (Verified Carbon Standard 2017) could offer potential pathways for investment. The ROC has already submitted a reference level to the UNFCCC, which, although it acknowledges the presence of peat soils, does not include soil organic carbon in its calculations, and notes limited emissions to date (Coordination Nationale REDD République du Congo 2017). The DRC has been developing its REDD+ 
plans on a similar basis. REDD+ funds are most readily available to regions where there is a clear plan to tackle a quantifiable threat to carbon stocks, so that results-based payments can be made for successful reductions in projected greenhouse gas emissions. Further research in both the natural and social sciences to evaluate more fully the threats discussed in Section 3 above, and their spatial variation, could help to make a case for future REDD+ and other climate change mitigation projects in Congolese peatlands, to the benefit of local inhabitants.

Increasingly, there is a move worldwide towards developing and investing in projects which meet multiple environmental and social objectives, including both climate change mitigation and ecosystem-based adaptation (Munroe and Mant 2014). An example, the first project funded by the UN's Green Climate Fund, has recently been inaugurated in Datem del Marañón Province, Peru (Green Climate Fund 2017; Roucoux et al. 2017). This US\$9.1-M project aims to develop 'bio-businesses' that allow sustainable conservation of peatland resources, favouring climate change adaptation, avoiding damage to carbon stocks, whilst also facilitating economic development and helping to meet social justice aims, such as the empowerment of women. It does not expect to claim results-based payments for the reduction in deforestation, but rather to establish a green economy (an environmentally sustainable economy which promotes social justice) not dependent on carbon funds. This could offer a template for similar investment on a much larger scale in the Congo Basin.

\subsection{Summary and research recommendations}

The peatlands of the Cuvette Centrale are carbon-rich ecosystems supporting highly valued but also vulnerable vertebrate species. Here, we have highlighted the potential threats to these peatlands, which include climate change, hydrocarbon exploration, logging, large-scale agriculture and the possible synergies between them. At present, the Cuvette Centrale peatlands are relatively intact and many of the threats may appear somewhat distant. Now is therefore the time to take action to ensure their protection. We suggest that conservation activities could be funded through a combination of climate, biodiversity and development funding, using the existing Ramsar designations that cover most of the peatlands as a framework for design and implementation of comprehensive management plans that protect the hydrology from modification. There is ongoing work on land-use planning in the Congo Basin through the Central African Forests Initiative, which could provide an opportunity to clarify national policies for peatland protection and management and integrate them into wider planning.

Our ability to assess the threat from, for example, climate change to the peatlands is limited by our lack of knowledge of the past response of the peatlands to climatic changes, their present-day hydrology and the future climate of the region over the twenty-first century. Much is still to be done to fully understand the form and function of these peatland ecosystems, and to assess their vulnerabilities. Whilst ultimately decisions over a nation's socio-economic development priorities are beyond the remit of the scientific community, researchers can identify and address knowledge gaps and do more to ensure that new research findings reach key decision makers. One critical research gap is our lack of understanding of the interplay between peat, fauna and flora, and local livelihoods. For example, as has also been demonstrated for South East Asian peatlands (Thornton et al. 2016), we know that local populations depend heavily on fishing as a key source of protein, and that some of that fishing takes place within the peat swamps themselves. But we do not 
know how fish populations in the rivers and swamps are connected, if at all, nor what additional diversity, and/or resource resilience, is supported by peatland habitats within the landscape as a whole. This is just one example of the possible synergies that might exist between carbon, biodiversity and socio-economic motivations for the careful management of Cuvette Centrale peatlands. Future research therefore needs to integrate knowledge from local communities, the natural sciences and social sciences, to develop a more holistic understanding of the Cuvette Centrale peatlands and facilitate local communities and their governments to manage and protect this globally significant region.

Acknowledgments We thank B. Mac Sharry (UNEP-WCMC), C. Ravilious (UNEP-WCMC) and H. Rainey (Wildlife Conservation Society) for providing information on Ramsar sites within the ROC and DRC and P. Gulliver (NERC Radiocarbon Facility) for radiocarbon analyses.

Funding information The peatlands research was funded by Natural Environment Research Council Open CASE award (ref. no. 1087746) to S.L.L. and G.C.D.; NERC Radiocarbon Facility NRCF010001 (alloc. no. 1688.0313 and 1797.0414) to I.T.L., S.L.L. and G.C.D.), Phillip Leverhulme Prize (to S.L.L.) and the Wildlife Conservation Society-Congo (to G.C.D).

\section{References}

Ahrends A, Burgess ND, Milledge SAH, Bulling MT, Fisher B, Smart JCR, Clarke GP, Mhoro BE, Lewis SL (2010) Predictable waves of sequential forest degradation and biodiversity loss spreading from an African city. PNAS 107(33):14556-14561. https://doi.org/10.1073/pnas.0914471107

Arellano P, Tansey K, Balzter H, Boyd DS (2015) Detecting the effects of hydrocarbon pollution in the Amazon forest using hyperspectral satellite images. Environ Pollut 205:225-239. https://doi.org/10.1016/j. envpol.2015.05.041

Barnston AG, Tippett MK, L'Heureux ML et al (2012) Skill of real-time seasonal ENSO model predictions during 2002-11: is our capability increasing? Bull Am Meteorol Soc 93(5):631-651. https://doi.org/10.1175 /BAMS-D-11-00111.1

Betbeder J, Gond V, Frappart F et al (2014) Mapping of Central Africa forested wetlands using remote sensing. IEEE J Sel Top Appl Earth Obs Remote Sens 7:531-542

Bonifica S.p.A (2017) Transaqua: Africa Sahel. http://bonifica2.accentra.it/water/transaqua-an-idea-for-thesahel/. Accessed 22 Nov 2017

Brncic TM, Willis KJ, Harris DJ, Washington R (2007) Culture or climate? The relative influences of past processes on the composition of the lowland Congo rainforest. Philos Trans R Soc Lond Ser B Biol Sci 362(1478):229-242. https://doi.org/10.1098/rstb.2006.1982

Buiter SJH, Steinberger B, Medvedev S, Tetreault JL (2012) Could the mantle have caused subsidence of the Congo Basin? Tectonophysics 514-517:62-80

Bwangoy JB, Hansen MC, Roy DP et al (2010) Wetland mapping in the Congo Basin using optical and radar remotely sensed data and derived topographical indices. Remote Sens Environ 114(1):73-86. https://oi. org/10.1016/j.rse.2009.08.004

Chimner RA, Cooper DJ, Wurster FC, Rochefort L (2016) An overview of peatland restoration in North America: where are we after 25 years? Restor Ecol 25:283-292

Coordination Nationale REDD République du Congo (2017) Niveau d'émissions de référence pour les forêts (NERF) de la République du Congo. UN-REDD Programme, Geneva

Crosby AG, Fishwick S, White N (2010) Structure and evolution of the intracratonic Congo Basin. Geochem Geophys Geosyst Q06010(6). https://doi.org/10.1029/2009GC003014

Daly MC, Lawrence SR, Diemu-Tshiband K, Matouana B (1992) Tectonic evolution of the Cuvette Centrale, Zaire. J Geol Soc Lond 149(4):539-546. https://doi.org/10.1144/gsjgs.149.4.0539

Dargie GC, Lewis SL, Lawson IT, Mitchard ETA, Page SE, Bocko YE, Ifo SA (2017) Age, extent and carbon storage of the central Congo Basin peatland complex. Nature 542(7639):86-90. https://doi.org/10.1038 /nature21048

Edwards DP, Sloan S, Weng L, Dirks P, Sayer J, Laurance WF (2014) Mining and the African environment. Conserv Lett 7(3):302-311. https://doi.org/10.1111/conl.12076 
Fabricius P (2016) The World Bank has suspended funding for the DRC's Inga 3 hydropower scheme. Where does this leave the project? ISS Today https://issafrica.org/iss-today/inga-dream-again-deferred. Accessed 15 Jul 2017

Fay JM, Agnagna M (1991) A population survey of forest elephants (Loxodonta africana cyclotis) in northern Congo. Afr J Ecol 29:177-187

Fay JM, Agnagna M, Moore J, Oko R (1989) Gorillas (Gorilla gorilla gorilla) in the Likouala swamp forests of north central Congo: preliminary data on populations and ecology. Int J Primatol 10(5):477-486. https://doi. org/10.1007/BF02736372

Finer M, Jenkins CN, Pimm SL, Keane B, Ross C (2008) Oil and gas projects in the western Amazon: threats to wilderness, biodiversity, and indigenous peoples. PLoS One 3(8):e2932. https://doi.org/10.1371/journal. pone. 0002932

Fotso-Nguemo TC, Vondou DA, Tchawoua C, Haensler A (2016) Assessment of simulated rainfall and temperature from the regional climate model REMO and future changes over Central Africa. Clim Dyn 48:3685-3705

Giles J (2005) Solving Africa's climate-data problem. Nature 435:863-863

Global Forest Watch (2017a) Democratic Republic of the Congo mining permits. http://data.globalforestwatch. org/datasets/3b4c0c91306c47abaec0c3fd46088242_5?uiTab=metadata. Accessed 25 Jul 2017

Global Forest Watch (2017b) Republic of the Congo mining permits. http://data.globalforestwatch. org/datasets/84fbbcc10c9f47f890750dd42426cbd2_18. Accessed 25 Jul 2017

Global Forest Watch (2017c) Democratic Republic of the Congo forest titles. http://data.globalforestwatch. org/datasets/535eb1335c4841b0bff272b78e2cc2f4_6. Accessed 25 Jul 2017

Global Forest Watch (2017d) Republic of the Congo logging concessions. http://data.globalforestwatch. org/datasets/557bfc901c584b7a8884aa455cfa6de2_19. Accessed 25 Jul 2017

Green Climate Fund (2017) Project FP001: building the resilience of wetlands in the province of Datem del Marañón, Peru. http:/www.greenclimate.fund/-/building-the-resilience-of-wetlands-in-the-province-ofdatem-del-maranon-peru. Accessed 21 Jul 2017

Grootjans A, Iturraspe R, Lanting A, et al (2010) Ecohydrological features of some contrasting mires in Tierra del Fuego, Argentina. Mires Peat 6:Article 1 1-15

Haensler A, Saeed F, Jacob D (2013) Assessing the robustness of projected precipitation changes over central Africa on the basis of a multitude of global and regional climate projections. Clim Chang 121(2):349-363. https://doi.org/10.1007/s10584-013-0863-8

Hansen MC, Potapov P V., Moore R, et al (2013) High-resolution global maps of 21st-century forest cover change. Science 342:850-853. Data available on-line from: http://earthenginepartners.appspot.com/science2013-global-forest

Hashimoto C, Tashiro Y, Kimura D, Enomoto T, Ingmanson EJ, Idani G, Furuichi T (1998) Habitat use and ranging of wild bonobos (Pan paniscus) at Wamba. Int J Primatol 19(6):1045-1060. https://doi.org/10.1023 /A:1020378320913

Hooijer A, Page S, Canadell JG, Silvius M, Kwadijk J, Wösten H, Jauhiainen J (2010) Current and future $\mathrm{CO}_{2}$ emissions from drained peatlands in Southeast Asia. Biogeosciences 7(5):1505-1514. https://doi. org/10.5194/bg-7-1505-2010

Huijnen V, Wooster MJ, Kaiser JW, Gaveau DLA, Flemming J, Parrington M, Inness A, Murdiyarso D, Main B, van Weele M (2016) Fire carbon emissions over maritime southeast Asia in 2015 largest since 1997. Sci Rep 6(1):26886. https://doi.org/10.1038/srep26886

Inogwabini B, Abokome M, Kamenge T et al (2012) Preliminary bonobo and chimpanzee nesting by habitat type in the northern Lac Tumba Landscape, Democratic Republic of Congo. Afr J Ecol 50:285-298

International Rivers (2017) The Inga 3 hydropower project. https://www.internationalrivers.org/campaigns/theinga-3-hydropower-project. Accessed 15 Jul 2017

James R, Washington R, Rowell DP (2013) Implications of global warming for the climate of African rainforests. Philos Trans R Soc Lond Ser B Biol Sci 368(1625):20120298. https://doi.org/10.1098/rstb.2012.0298

Jauhiainen J, Hooijer A, Page SE (2012) Carbon dioxide emissions from an Acacia plantation on peatland in Sumatra, Indonesia. Biogeosciences 9(2):617-630. https://doi.org/10.5194/bg-9-617-2012

Jung HC, Hamski J, Durand M, Alsdorf D, Hossain F, Lee H, Hossain AKMA, Hasan K, Khan AS, Hoque AKMZ (2010) Characterization of complex fluvial systems using remote sensing of spatial and temporal water level variations in the Amazon, Congo, and Brahmaputra rivers. Earth Surf Process Landf 35(3):294 304. https://doi.org/10.1002/esp.1914

Kadima E, Delvaux D, Sebagenzi SN, Tack L, Kabeya SM (2011) Structure and geological history of the Congo Basin: an integrated interpretation of gravity, magnetic and reflection seismic data. Basin Res 23(5):499527. https://doi.org/10.1111/j.1365-2117.2011.00500.x

Könönen M, Jauhiainen J, Laiho R, Spetz P, Kusin K, Limin S, Vasander H (2016) Land use increases the recalcitrance of tropical peat. Wetl Ecol Manag 24(6):717-731. https://doi.org/10.1007/s11273-016-9498-7 
Langner A, Siegert F (2009) Spatiotemporal fire occurrence in Borneo over a period of 10 years. Glob Chang Biol 15(1):48-62. https://doi.org/10.1111/j.1365-2486.2008.01828.x

Laprise R, Hernández-Díaz L, Tete K, Sushama L, Šeparović L, Martynov A, Winger K, Valin M (2013) Climate projections over CORDEX Africa domain using the fifth-generation Canadian Regional Climate Model (CRCM5). Clim Dyn 41(11-12):3219-3246. https://doi.org/10.1007/s00382-012-1651-2

Laraque A, Mahé G, Orange D, Marieu B (2001) Spatiotemporal variations in hydrological regimes within Central Africa during the XXth century. J Hydrol 245(1-4):104-117. https://doi.org/10.1016/S0022-1694(01)00340-7

Laraque A, Bricquet JP, Pandi A, Olivry JC (2009) A review of material transport by the Congo River and its tributaries. Hydrol Process 23(22):3216-3224. https://doi.org/10.1002/hyp.7395

Laurance WF, Campbell MJ, Alamgir M, Mahmoud MI (2017) Road expansion and the fate of Africa's tropical forests. Front Ecol Evol 5:Article 75. https://doi.org/10.3389/fevo.2017.00075.

Lee H, Yuan T, Jung HC, Beighley E (2015) Mapping wetland water depths over the central Congo Basin using PALSAR ScanSAR, Envisat altimetry, and MODIS VCF data. Remote Sens Environ 159:70-79. https://doi. org/10.1016/j.rse.2014.11.030

Lewis J (2002) Forest hunter-gatherers and their world: a study of the Mbendjele Yaka pygmies of Congo-Brazzaville and their secular and religious activities and representations. Doctoral Thesis, University of London

MapforEnvironment (2017a) Oil Blocs 2013. https://mapforenvironment.org/layer/info/184/\#4.65/-3.013 21.755. Accessed 4 Aug 2017

MapforEnvironment (2017b) DRC protected areas. https://mapforenvironment.org/layer/info/193/\#4.38/-3.547 /21.568. Accessed 25 Jul 2017

Marengo JA (1998) Climatologia de la zona de Iquitos, Peru. In: Kalliola R, Flores Paitan S (eds) Geoecologia y desarrollo amazonico: studio intergrado en la zona de Iquitos, Peru. Annales Un. University of Turku, Finland, pp 35-57

Master S (2010) Lac Télé structure, Republic of Congo: geological setting of a cryptozoological and biodiversity hotspot, and evidence against an impact origin. J Afr Earth Sci 58(4):667-679. https://doi.org/10.1016/j. jafrearsci.2009.07.017

Mayaux P, Bartholomé E, Fritz S, Belward A (2004) A new land cover map of Africa for the year 2000. J Biogeogr 31(6):861-877. https://doi.org/10.1111/j.1365-2699.2004.01073.x

Medrilzam M, Dargusch P, Herbohn J, Smith C (2014) The socio-ecological drivers of forest degradation in part of the tropical peatlands of Central Kalimantan, Indonesia. Forestry 87(2):335-345. https://doi.org/10.1093 /forestry/cpt033

Miettinen J, Shi C, Liew SC (2016) Land cover distribution in the peatlands of Peninsular Malaysia, Sumatra and Borneo in 2015 with changes since 1990. Glob. Ecol Conserv 6:67-78

Ministère des Hydrocarbones Républic du Congo \& SNPC (2016) Congo License Round 2016: Cuvette Basin. http:/www.congolr2016.com/cuvette-basin. Accessed 25 Jul 2017

Ministry of Climate and Environment, Kingdom of Norway (2017) Rainforest Foundation UK misleads the public about the international community's efforts to preserve Congo's forests. https://www.regjeringen. no/no/aktuelt/rainforest-foundation-uk-misleads-the-public-about-the-international-communitys-efforts-topreserve-congos-forests/id2564628/. Accessed 30 Sep 2017

Moore S, Evans CD, Page SE, Garnett MH, Jones TG, Freeman C, Hooijer A, Wiltshire AJ, Limin SH, Gauci V (2013) Deep instability of deforested tropical peatlands revealed by fluvial organic carbon fluxes. Nature 493(7434):660-664. https://doi.org/10.1038/nature11818

Munroe R, Mant R (2014) Info brief 2: REDD+ and adaptation: identifying complementary responses to climate change. UN-REDD Programme, Geneva

Niang I, Ruppel OC, Abdrabo MA, et al (2014) Africa. In: Barros VR, Field CB, Dokken DJ et al (eds) Climate change 2014: impacts, adaptation, and vulnerability. Part B: regional aspects. Contribution of Working Group II to the Fifth Assessment Report of the Intergovernmental Panel on Climate Change. Cambridge University Press, Cambridge, United Kingdom and New York, pp 1199-1265

Ordway EM, Asner GP, Lambin EF (2017) Deforestation risk due to commodity crop expansion in sub-Saharan Africa. Environ Res Lett 12(4):044015. https://doi.org/10.1088/1748-9326/aa6509

Oslisly R, Doutrelepont H, Fontugne M, et al (2006) Premiers résultats pluridisciplinaires d'une stratigraphie vieille de plus de 40.000 ans du site de Maboué 5 dans la réserve de la Lopé au Gabon. In: Actes du XIV Congrés de l’UISPP, Liége 2-8 September 2001, Préhistoire en Afrique, BAR International Series. pp 189-198

Page SE, Siegert F, Rieley JO, Boehm HDV, Jaya A, Limin S (2002) The amount of carbon released from peat and forest fires in Indonesia during 1997. Nature 420(6911):61-65. https://doi.org/10.1038/nature01131

Patterson L, Cooper DJ (2007) The use of hydrologic and ecological indicators for the restoration of drainage ditches and water diversions in a mountain fen, Cascade Range, California. Wetlands 27(2):290-304

Protected Planet (2017) The World Database on Protected Areas (WDPA). https://www.protectedplanet.net/. Accessed 25 Jul 2017 
Rainey HJ, Iyenguet FC, Malanda GF et al (2010) Survey of Raphia swamp forest, Republic of Congo, indicates high densities of critically endangered western lowland gorillas Gorilla gorilla gorilla. Oryx 44(01):124-132. https://doi.org/10.1017/S003060530999010X

Ramsar (2015) Ramsar COP12 Resolution XII.11. Peatlands, climate change and wise use: implications for the Ramsar Convention. Ramsar Convention Secretariat, Gland

Ramsar (2017a) Sites and countries. http://www.ramsar.org/sites-countries. Accessed 22 Jul 2017

Ramsar (2017b) Ramsar Sites Information Service. https://rsis.ramsar.org/ris-search/. Accessed 27 Jul 2017

Ramsar Convention Secretariat (2016) An Introduction to the Ramsar Convention on Wetlands. Sub-series I: Handbook 1. International Cooperation on Wetlands, 5th edn. Ramsar Convention Secretariat, Gland

Riddell M (2013) Assessing the impacts of conservation and commercial forestry on livelihoods in Northern Republic of Congo. Conserv Soc 11(3):199-217. https://doi.org/10.4103/0972-4923.121002

Rieley J (2001) Kalimantan's peatland disaster Inside Indonesia Edition 65. http://www.insideindonesia. org/kalimantans-peatland-disaster. Accessed 3 Aug 2017

Riley J, Huchzermeyer FW (1999) African dwarf crocodiles in the Likouala swamp forests of the Congo Basin: habitat, density, and nesting. Copeia 1999(2):313-320. https://doi.org/10.2307/1447477

Roucoux KH, Lawson IT, Baker TR, del Castillo Torres D, Draper FC, Lähteenoja O, Gilmore MP, Honorio Coronado EN, Kelly TJ, Mitchard ETA, Vriesendorp CF (2017) Threats to intact tropical peatlands and opportunities for their conservation. Conserv Biol 31(6):1283-1292. https://doi.org/10.1111 /cobi. 12925

Saatchi SS, Harris NL, Brown S, Lefsky M, Mitchard ETA, Salas W, Zutta BR, Buermann W, Lewis SL, Hagen S, Petrova S, White L, Silman M, Morel A (2011) Benchmark map of forest carbon stocks in tropical regions across three continents. PNAS 108(24):9899-9904. https://doi.org/10.1073/pnas.1019576108

Samba G, Nganga D, Mpounza M (2008) Rainfall and temperature variations over Congo-Brazzaville between 1950 and 1998. Theor Appl Climatol 91(1-4):85-97. https://doi.org/10.1007/s00704-007-0298-0

Shanahan TM, Mckay NP, Hughen KA et al (2015) The time-transgressive termination of the African Humid Period. Nat Geosci 8(2):140-144. https://doi.org/10.1038/ngeo2329

Susilo GE, Yamamoto K, Imai T, Ishii Y, Fukami H, Sekine M (2013) The effect of ENSO on rainfall characteristics in the tropical peatland areas of Central Kalimantan, Indonesia. Hydrol Sci J 58(3):539548. https://doi.org/10.1080/02626667.2013.772298

Takakai F, Morishita T, Hashidoko Y, Darung U, Kuramochi K, Dohong S, Limin SH, Hatano R (2006) Effects of agricultural land-use change and forest fire on $\mathrm{N}_{2} \mathrm{O}$ emission from tropical peatlands, Central Kalimantan, Indonesia. Soil Sci Plant Nutr 52(5):662-674. https://doi.org/10.1111/j.1747-0765.2006.00084.x

Terada S, Nackoney J, Sakamaki T, Mulavwa MN, Yumoto T, Furuichi T (2015) Habitat use of bonobos (Pan paniscus) at Wamba: selection of vegetation types for ranging, feeding, and night-sleeping. Am J Primatol 77(6):701-713. https://doi.org/10.1002/ajp.22392

The Lake Chad Basin Commission (2016a) Inter Basin Water Transfer Project: signing of a memorandum of understanding between LCBC and PowerChina International Group Limited. http://www.cblt. org/en/news/inter-basin-water-transfer-project-signing-memorandum-understanding-between-lcbc-andPowerChina. Accessed 22 Nov 2017

The Lake Chad Basin Commission (2016b) Interbasin Water Transfer Project (IBWTP). http://www.cblt. org/en/projects/interbasin-water-transfer-project. Accessed 22 Nov 2017

The Lake Chad Basin Commission (2016c) The Lake Chad Basin Commission. http://www.cblt.org/en. Accessed 22 Nov 2017

The Oil and Gas Year (2017a) Republic of Congo overview. http://www.theoilandgasyear.com/market/republicof-congo/. Accessed 15 Jul 2017

The Oil and Gas Year (2017b) Republic of Congo 2017. The Oil and Gas Year Ltd, Dubai

The Rainforest Foundation UK (2013) Seeds of destruction. The Rainforest Foundation UK, London

Thornton SA, Dudin, Limin SH, et al (2016) Peatland fish of Sabangau, Borneo: ecology and implications for future monitoring and conservation. In: Proceedings of the 15th International Peat Congress, Kuching, Malaysia, 15-19 August 2016. pp 723-727

UN-REDD Programme (2016) About REDD+. http://www.unredd.net/about/what-is-redd-plus.html. Accessed 21 Jul 2017

US Department of Commerce (2017) Congo, Democratic Republic_oil and gas. https://www.export. gov/article?id=Congo-Democratic-Republic-Oil-and-Gas. Accessed 25 Nov 2017

USDA Foreign Agricultural Service (2017) Oilseeds: world markets and trade (November 2017). USDA Foreign Agricultural Service, Washington

USGS (2016) Mineral commodity summaries 2016. USGS, Reston

Vancutsem C, Pekel JF, Evrard C, Malaisse F, Defourny P (2009) Mapping and characterizing the vegetation types of the Democratic Republic of Congo using SPOT VEGETATION time series. Int J Appl Earth Obs Geoinf 11(1):62-76. https://doi.org/10.1016/j.jag.2008.08.001 
Verhegghen A, Mayaux P, de Wasseige C, Defourny P (2012) Mapping Congo Basin vegetation types from 300 $\mathrm{m}$ and $1 \mathrm{~km}$ multi-sensor time series for carbon stocks and forest areas estimation. Biogeosciences 9(12): 5061-5079. https://doi.org/10.5194/bg-9-5061-2012

Verified Carbon Standard (2017) The VCS Program. http:/www.v-c-s.org/project/vcs-program/. Accessed 21 Jul 2017

World Bank (2016) World Bank Group suspends financing to the Inga-3 Basse Chute technical assistance project. http://www.worldbank.org/en/news/press-release/2016/07/25/world-bank-group-suspendsfinancing-to-the-inga-3-basse-chute-technical-assistance-project. Accessed 5 Jul 2017

Wright T, Rahmanulloh A (2017) Indonesia oilseeds and products annual report 2017. USDA Foreign Agricultural Service, Washington 